\title{
めり込みを考慮した RC 部材端部の回転変形解析法 ANALYSIS OF ROTATION AT END OF REINFORCED CONCRETE MEMBERS CONSIDERING SUBSIDENCE
}

\author{
今井和 正*, 是永 健 好*, 瀧口克已** \\ Kazumasa IMAI, Takeyoshi KORENAGA and Katsuki TAKIGUCHI
}

\begin{abstract}
When reinforced concrete members are subjected to bending moment, rotational deformation occurs in their ends. That deformation is generally considered to result from a slip of longitudinal bars, and some methods to estimate the rotational angle have been proposed. On the other hand, although a phenomenon that the members subside into the beam-column joints is observed, it has not been investigated. In this paper, it is insisted that the deformation results from a reciprocal action of the subsidence and the slip. A model to estimate the rotational angle considering the subsidence is proposed, and it gives good agreement with test results.
\end{abstract}

Keywords : reinforced concrete, column, beam, subsidence, rotation angle, stiffness 鉄筋コンクリート，柱，梁，めり込み，回転角，剛性

\section{1.はじめに}

鉄筋コンクリートの柱や梁などの部材変形は，一般に曲げ変形と せん断変形の累加として求められる。これらの部材で卓越する曲げ 変形は，平面保持解析により得られる曲率分布を基に求められ，塑 性化後においては塑性ヒンジ領域を設定してその変形を推定する方 法1などが一般的である。これは，多数の実験結果から設定されたも のであり，部材の巨視的な変形を適切にかつ簡便に推定できる優れ た手法であるが，理論的な裏付けが十分なされているとは言い難 い。したがって, 曲げが卓越する通常の部材においても, 部材内各 部のひずみを十分な精度で推定できないため, 限界耐力計算に必要 な限界部材角を厳密な意味では設定できない現状にある。

これらの変形に加えて, 梁と柱梁接合部の境界にも回転変形が生 じることが知られている。勒性保証型設計指針 ${ }^{2)}$ には主筋の抜け出し に起因する付加回転バネを考慮することで部材の変形を精度良く評 価できることが述べられており，実験結果から統計的に得た抜け出 し量の推定法が紹介されている。文献3)では，文献2) と同様の考之 方に基づいて抜け出し量を求め，これを回転中心から引張主筋まで の距離で除して付加回転角を推定する方法が提案されている。この 方法では, 森田らが文献4)で設定した仮定に基づき, 回転中心位置 として中立軸位置が近似的に用いられている。杭頭の回転変形の推 定を試みた文献5)においても, 実験と平面保持解析との比較から上 述の近似が成り立つことを確認した上で，同様の手法によって回転 変形を推定する方法が示されている。しかしながら，ここで用いら
れる近似は，部材からの曲げ圧縮力に対する接合部コンクリートの 剛性によって，その精度が变化するものと推測できる（図1参照）。 つまり，抜け出し量が等しくても，接合部コンクリートの剛性が小 さいほどめり込み量が多くなり，回転中心位置が引張主筋側に移動 して大きな回転角が生じることになる。したがって，回転中心位置 は主筋の抜け出しと接合部へのめり込みの相互作用を考慮して求め る必要があると考えられる。

これまで検討対象とされてきた部材では，その端部回転変形を抜 け出し量のみの評価によって十分な精度で推定できたため，めり込 み現象の存在自体は認識されていたものの，その定量的な評価法に 関する研究は行われていない。これは，めり込みと抜け出しにそれ ぞれ影響を与える材料特性が，前記の近似からかけ離れないための

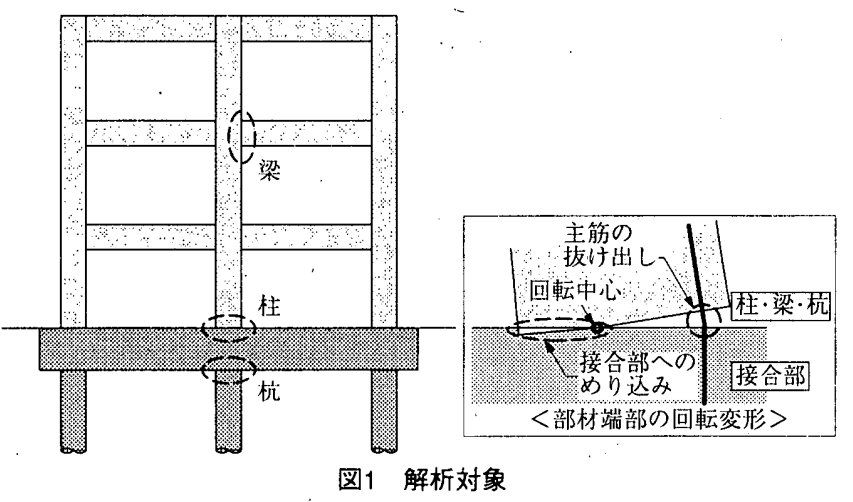

* 大成建設(例技術センター建築技術研究所 工修

** 東京工業大学 教授. 工博
Building Engineering Research Institute, Technology Center, Taisei Corporation, M. Eng.

Prof., Tokyo Institute of Technology, Dr. Eng. 
条件を満たしていたものと考えられるが, 近年の材料の高強度化に よってこれまでは無視されてきた現象が顕在化する可能性がある。 例えば，圧縮強度が $100 \mathrm{~N} / \mathrm{mm}^{2}$ 級の高強度コンクリートを用いたRC 柱の曲げせん断実験のによれば，従来の方法では初期剛性を精度良く 推定できないことが報告されている。

また，基礎梁や基礎マットの合理化などの目的で近年開発された 杭頭半剛接工法8.97では，杭頭の回転剛性を低隇するために杭頭部の 断面が軸部に比べて縮小されている場合があり，これを模擬した実 験ではフーチングへのめり込みが観察されている。この工法では, 杭主筋がフーチングに定着されていないため，杭の変形の大部分を 占める杭頭回転角を前述の主筋の抜け出し変形から求める方法では 算定できない。このように，性能規定化，限界耐力計算の導入に伴 う部材の多様化に対応するためにも，端部回転変形の評価法確立は 必要不可欠となってきている。

本論文では, 部材端部の回転変形評価法を構築するための第一段 階として，上述のめり込み現象に着目し，これによって生じる回転 角を簡便に推定する方法を提案する。図1に示すように，柱梁接合部 への梁のめり込み，基礎梁への柱のめり込み，フーチングへの杭の めり込みなどを対象とする。梁，柱および杭などを「部材」と呼 び，柱梁接合部，基礎梁およびフーチングに相当する部分を「接合 部」と呼ぶこととする。

\section{2. 軸力作用時のめり込み量の推定}

まず，部材に曲げモーメントが作用せず，軸力のみが作用すると きのめり込み量の推定法について述べる。

図2に示すように半無限大の弾性体に円形の等分布荷重が作用する 場合, 中心位置における深さ $z$ での軸方向変位量. (沈下量) は, 弾性 論により次式で与えられる10)。

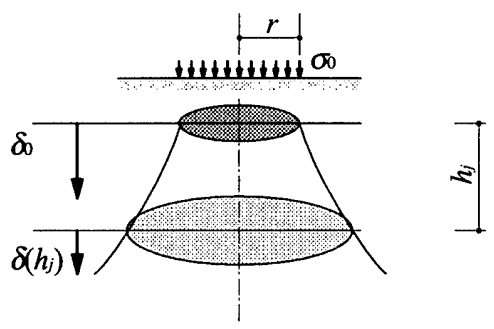

図2 円形等分布荷重が作用する半無限弾性体のめり込み

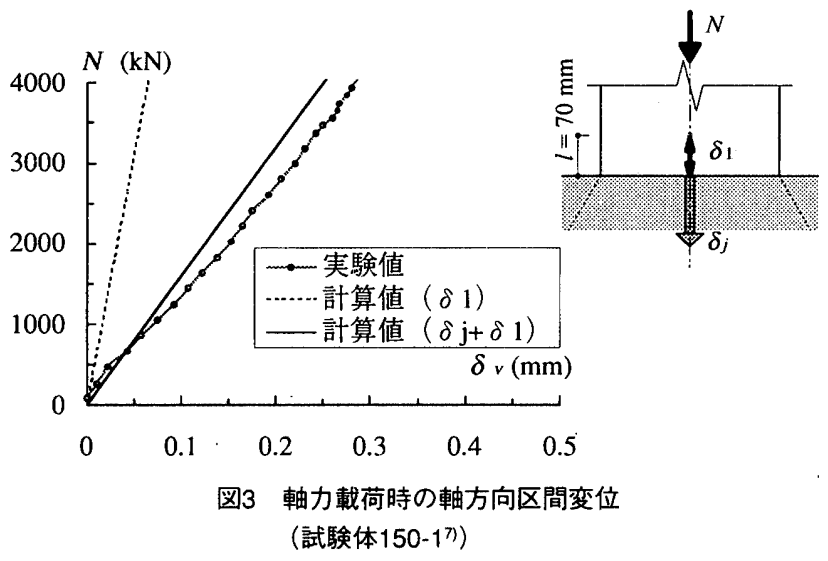

$\delta(z)=-\frac{2 r \sigma_{0}\left(1-v^{2}\right)}{E}\left(\sqrt{1+\frac{z^{2}}{r^{2}}}-\frac{z}{r}\right)\left\{1+\frac{z / r}{2(1-v) \sqrt{1+z^{2} / r^{2}}}\right\}$

ここに, $r:$ 接触面の半径, $\sigma_{0}$ : 接触面に作用する圧縮応力 $E, v:$ 弾性体のヤング率とポアソン比

ここでは，接合部の水平断面が部材断面より十分に大きいものと考 え，近似的に式(1)が成り立つものとする。

部材底面での变位量 $\delta_{0}$ は式(2)によって求めることができる。 0.785 は, 部材底面が面外変形に対して剛であると仮定した場合の係数で ある"1。

$$
\delta_{0}=0.785 \delta(0)=-0.785 \frac{2 r \sigma_{0}\left(1-v^{2}\right)}{E}
$$

接合部の深さをん, とすれば，めり込みによる変形量 $\delta$, は次式で与えら れる。

$$
\delta_{j}=\delta_{0}-\delta\left(h_{j}\right)
$$

なお，部材断面が矩形の場合には，面積が等しい円の半径を各式の のの值として算出する。

文献7）の柱の曲げせん断実験（試験体150-1）で得られている軸方 向変位量の実測値を計算值と比較して図3に示す。試験体は，断面が $300 \times 300 \mathrm{~mm}$ ，内法高さが $900 \mathrm{~mm}$ で，主筋にUSD685，コンクリー トに $150 \mathrm{~N} / \mathrm{mm}^{2}$ 級の高強度材料を用いたものである。実測值は軸力 （ $M$ ）を載荷したとき（曲げせん断加力前）における，柱端部の区 間変位（㭘長 $l=70 \mathrm{~mm}$ ）である。点線は計測区間内の柱の弾性縮 み量計算值 $\delta_{1}$ を示し，実線はこれに式(3)で得られるスタブへのめり 込み量計算值 $\delta_{j}$ を累加した值である。 $\delta_{j}$ を考慮することで軸方向剛性 が適切に評価できている。ここでは図示しないが，端部区間を除く 他の部分の变形量は弾性縮み量計算值（上述の $\delta_{1} に$ 相当）と同等と なっている。

\section{3.めり込みによって生じる回転角の推定}

\section{1 部材端部の回転剛性}

2 章に示しためり込み量 $\delta_{j}$ を用いて，曲げによって生じる部材端部 回転角 $\theta$ を推定する。接触面積が同一であれば，その応力重心位置 におけるめり込み量は均一応力が円形に分布する場合と等しいもの と仮定する。また，コンクリートの圧縮応力が 0 の点を回転中心と し，ここから応力重心位置までの距離で $\delta$ を除すことにより $\theta_{j}$ を求め る。

モーメントー回転角関係（以後， $M-\theta$ 関係）における初期剛性 （以後，回転剛性）の推定法について述べる。図4に示すように, 部 材に軸力 $N$ 作用し，曲げモーメントMによって接触面での引張縁応 力が 0 となるとき（以後，離間時と記す）のモーメント $M_{s}$ と回転角 㨻はそれぞれ式(4)，式(5)によって得られる。

$$
\begin{aligned}
& M_{s}=Z_{e} \sigma_{0} \\
& \theta_{j s}=\frac{\delta_{j}}{D / 2+e}
\end{aligned}
$$

ここに, $D:$ 接触面の直径またはせい, $e:$ 偏心距離 $(=M / M)$ 2章にも示した柱の逆対称曲げせん断実験》（試験体150-1）で得 られている材端の $M-\theta$ 関係の加力初期部分を, 計算結果と比較して 図5に示す。実験值はスタブフェイス面から検長 $l=70 \mathrm{~mm}$ の区間 で計測された回転角であり，この区間内の曲げによる成分 $\theta_{1}$ と，基 


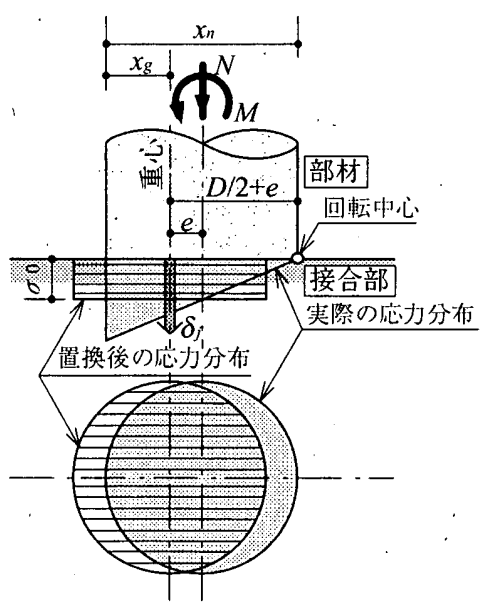

図4離間時のめり込み

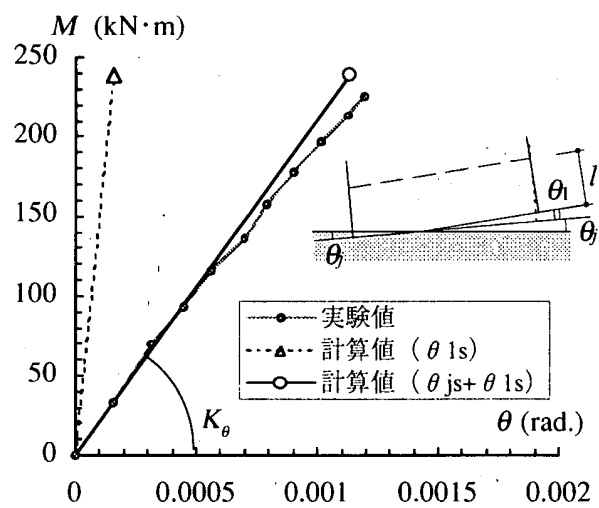

図5 部材端部のモーメントー回転角関係 (試験体150-17)

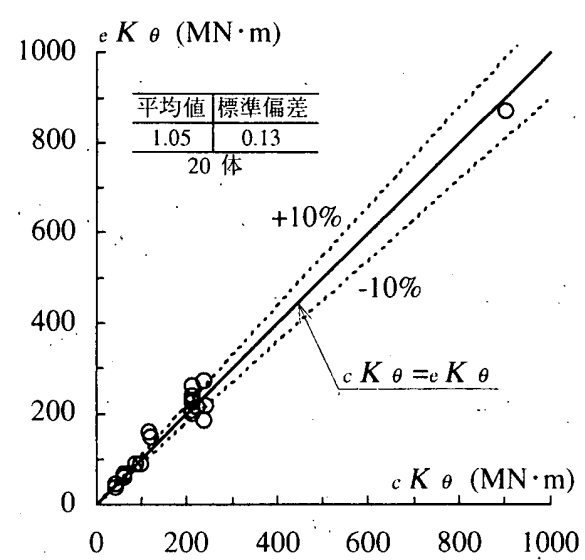

図6，部材端部の回転剛性実験值と 計算値の比較
礎スタブへのめり込みによる成分 $\theta$ ，含んでいる。図5中の $\Delta$ 印は, 接触面が離間する時の曲げ成分計算值 $\theta_{1 s}$ で，○印はこれに式(5)で求 めためり込みによる成分 $\theta_{j s}$ を考慮した結果である。 $\theta_{1 s}$ のみでは回転 剛性を過大に評価しているが， $\theta_{j s}$ を考慮することによって適切に評 価できている。この試験体では $\theta_{1 s}: \theta_{j s}$ は $1: 6$ 程度となっており, めり込みによる回転変形を考慮することが重要であることを示唆し ている。

上述の2式から得られる部材端部の回転剛性計算值 $K_{c}(=M)$ $\left(\theta_{j s}+\theta_{1,}\right)$ を実験值 $K_{\theta}$ と比較して図6に示す。実験值は, 部材端部の 区間変形が計測されている文献(6) -9，12)の柱および杭の実験結果（試 験体数 20 体）である。多少のばらつきはあるものの上述の方法で 回転剛性が概ね適切に推定できていると言える。

\section{2 部材の剛性}

部材端部における回転剛性が，提案した簡便な方法によって推定 できることを前節で示した。ここでは，この回転変形を考慮してせ ん断力一水平変位関係（以後， $Q-\delta$ 関係）上の初期剛性を求め, 実験 結果と比較する。

柱の曲げせん断実験7（試験体150-1）で得られている $Q-\delta$ 関係の 加力初期の部分を，計算結果と比較して図7に示す。点線は，初等梁 理論による曲げ剛性 $K_{b}$ とせん断剛性 $K_{s}$ から求められる初期剛性（計 算値1）で，一点鎖線は文献 ${ }^{13.3}$ に基づき可撓長さを用いて求めた初期
剛性（計算值2）である。可撓長さは内法スパンに $0.25 D$ 両端に加 えた值（ $D$ : 部材せいまたは直径）とした。実線は3.1節に示しため り込みによる回転変形を考慮して，次式で得られる初期剛性（計算 值3）である。

$$
K=\frac{1}{1 / K_{b}+1 / K_{s}+1 / K_{r}}
$$

ここで， $K$ は回転で生じる水平変位に対する剛性で，下式で求め た。

$$
\begin{aligned}
& K_{r}=\frac{M_{0 e} /(L / 2)}{\theta_{0 e} L}=\frac{2 K_{\theta}}{L^{2}} \\
& \text { ここに, L: 内法スパン }
\end{aligned}
$$

計算值1は初期剛性実験値より5割程度大きな値となっている。一方， 計算値2と計算值3はいずれもこの試験体の初期剛性とほほ等しい。

図8にQ- $\delta$ 関係上の初期剛性の計算值と実験值の関係を示す。実験 值は文献(3) 7),14) -17) の49体の逆対称曲げせん断実験の結果である。図 中の口印， $\triangle$ 印および○印はそれぞれ上述の計算值 $1 ， 2$ および3であ る。実験值と計算值3の比の平均值は 0.99 , 標準偏差は 0.10 で, 剛性 が適切に評価できていると言える。設計に常用されている計算值2の 推定精度も計算值3と同等で高いが，部材と接合部で材料の剛性が異 なる場合に推定精度が低下すると推測される。めり込みによって生 じる回転角は接合部のコンクリートの剛性によって実際には変化す

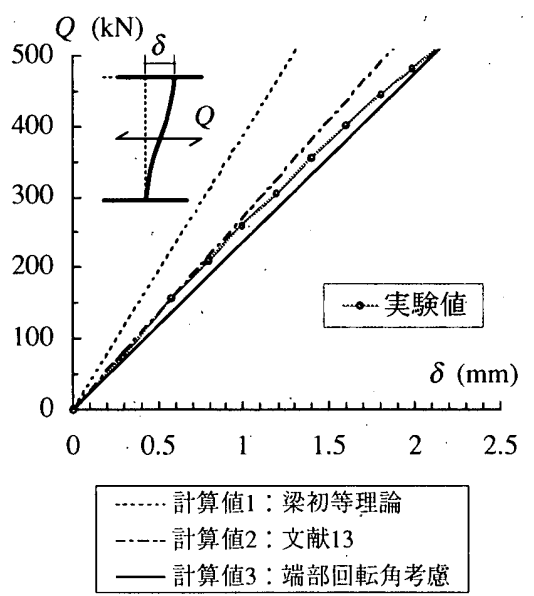

図7 せん断カ一水平変位関係（試験体150-17)

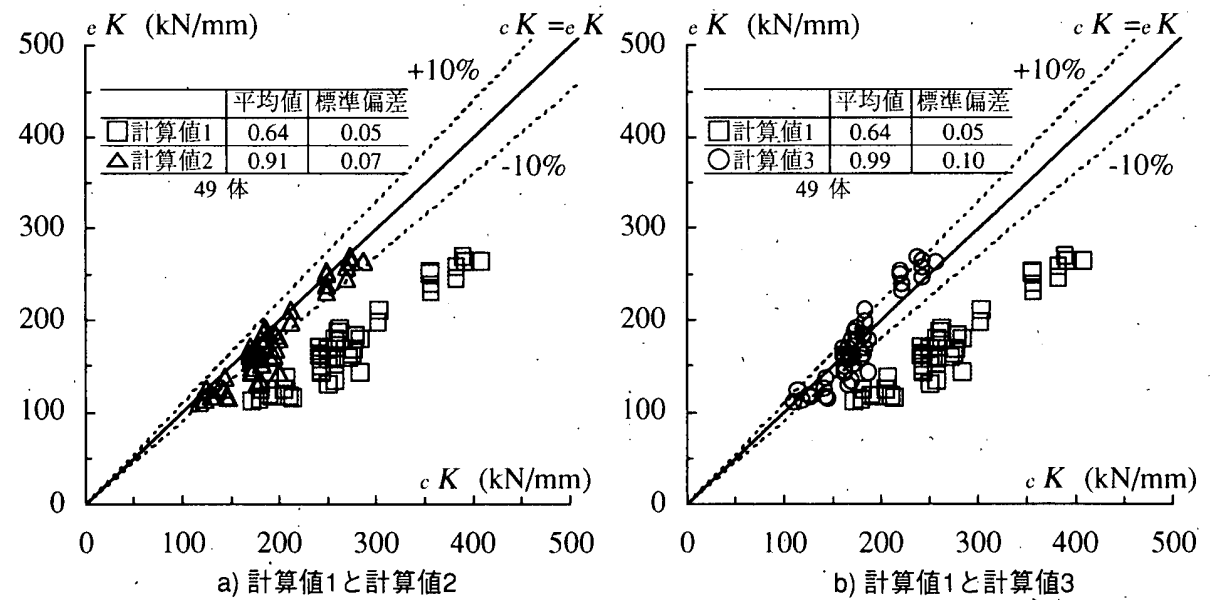

図8剛性の実験值と計算値の比較 
ると考えられるが, 計算值2の方法ではこの影響が取り入れられて いないためである。また，この方法では接合部内の可撓長さを部材 せいの0.25倍と仮定しているが，次章の図9a)に示すような変断面を 有する部材の場合，可撓長さを設定する方法が明確ではない。本論 で提案する手法ではめり込みによる回転角を直接求められるため, このような部材に対しても剛性算定が可能である。

\section{4. 曲げモーメントー回転角関係の解析法}

3章では, 部材が接合部にめり込むことで生じる回転角の評価法に ついて述べ, 部材端部の $M-\theta$ 関係および部材全体の $Q-\delta$ 関係上の初期 剛性を実験值と比較してその妥当性を示した。ここでは，文献8)の 主筋非定着杭試験体No.1を例に, 部材が弾性範囲を超えた領域, 寸な わち接触面か離間した後も含めた $M-\theta$ 関係の推定法について述べる。

試験体No.1の杭頭部周辺の形状を図9a)に示す。杭頭部は軸部に比 べて断面が縮小されており，杭主筋は基礎に定着されていない。コ ンクリート強度, 軸応力度等は後で表1に示す通りで, 基礎スタブ のコンクリート強度は杭頭よりも小さくなっている。これらの形 状, 材料强度の条件下では, 本論で着目しているめり込みが生じや すいため, 解析法を構築, 検証する上で有用だと考え, ここでの対 象に選んだ。また，回転变形に主筋の抜け出しを考慮する必要がな いため，検討をより単純化できる。加力は図9b)に示すとおり不静定 梁形式の正負交番繰り返し載荷であり, 杭頭の回転角は $90 \mathrm{~mm}$ の 区間で計測されている。加力時に接触面の引張側で杭と基礎スタブ 間の離間が観察され, 加力終了後 (杭撤去後)には基礎スタブ側に 深さ $1 \mathrm{~mm}$ 程度の残留めり込みが確認されている。

\section{1 解析モデル}

ここでは，めり込みによって部材端部に生じる回転角の推定法に ついて，その手順と基本仮定を述べる。詳細な設定事項などについ ては4.1.1〜4.1.3項に示す。

手順 1 : 部材端部の断面解析により曲げモーメント $M$, 曲率 $\phi$, 回転 中心深さ $x_{n}$, コンクリートの応力重心深さ $x_{g}$ を求める（図10a),b)）。 手順 2 : コンクリートの応力重心位置 $\mathrm{G}$ におけるめり込み量 $\delta$,を求め る(図10c),d)）。

手順 3 : めり込みによる回転角 $\theta$ ，を算出する（図10e)）。

「手順 $2 」 の \delta_{j}$ の算定にあたり, 計算の簡略化を図って以下の仮定 を設ける。

仮定(1)：支圧面積が同一であれば，その応力重心位置におけるめり 込み量は，均一応力が円形に分布する場合と等しいものと考える (図10c)）。

仮定(2)：接合部コンクリートの応力は，部材軸と $\alpha$ の角をなす円錐 台状に拡がるものと仮定する（図10d)）。

部材と接合部との接触面（支圧面）の形状は, 回転角 $\theta_{j}$ の增加に 伴う引張側での浮上がりによって変化する。これとともに接合部に は偏心載荷状態でのめり込みが生じる。本論では，接触面の形状と 偏心によって重心位置でのめり込み量 $\delta$ 更変化しないものとし, 上 記の仮定(1)を設けた。なお，偏心の影響を無視するのは，3.1節で述 ベた $M-\theta$ 関係の初期剛性の算定時と同じである。

接合部のコンクリートを弾性体と仮定すれば, めり込み量 $\delta_{j}$ は 2 章に示した方法で理論的に求められるが，非線形域までを対象とす る場合にはこの弾性計算を適用できない。したがって，4.1.1項に示

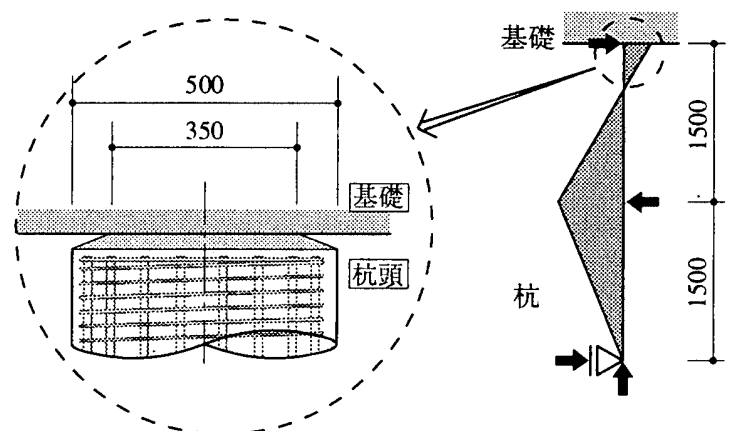

a) 杭頭部の形状

b) 加力方法

図9主筋非定着杭試験体No. $1^{8}$

a)

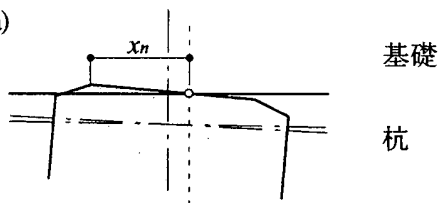

b) $\mid 1$ 応力重心位置 $\mathrm{G}$

c)

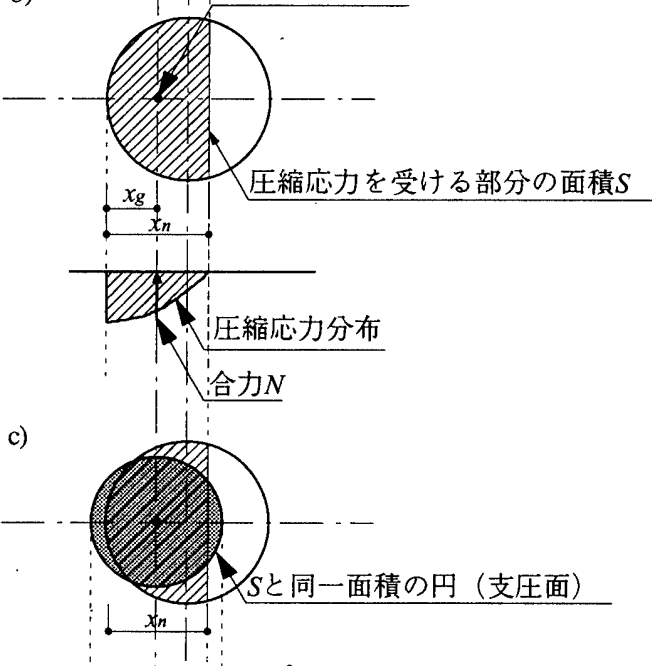

d)

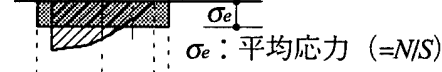
$\sigma_{e}:$ 平均応力 $(=N / S)$

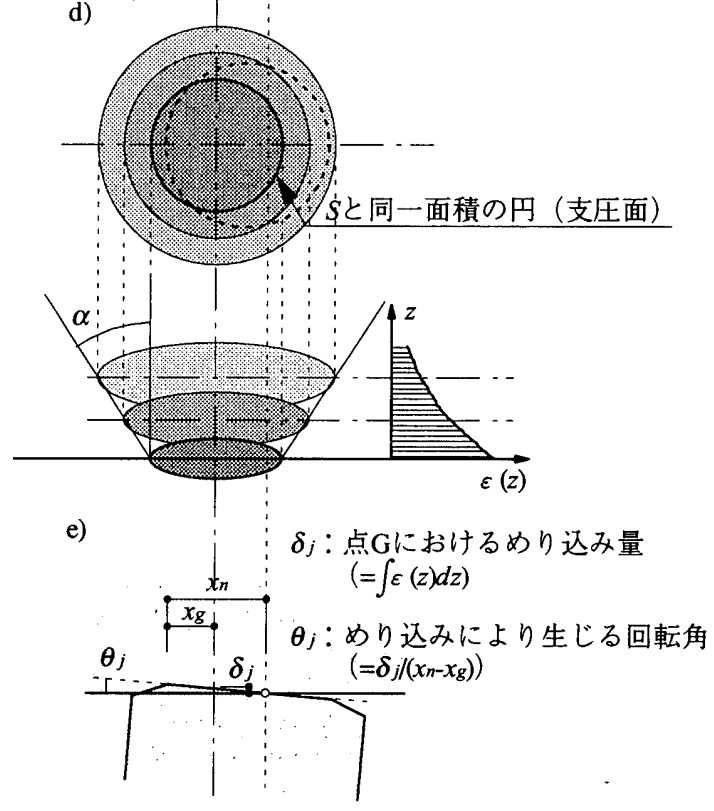

図10 解析手順 
す方法により弾性時の応力の拡がり角度 $\alpha$ を設定し, 非線形域にお いてもこの角度を仮定してめり込み量 $\delta$ 救めることとした（仮定 (2)）。このように置換することにより， $\delta_{j}$ は接合部内のひずみを深 さ方向に積分すれば簡便に得られる。

以上をまとめて，「手順 $2 」$ 」内容をより具体的に述べる。ま ず，仮定(1)に基づいて，接触面を面積と応力重心位置Gがともに等 しい円（平均応力 $\sigma_{e}$ を受ける支圧面）に置換する（図10c)）。仮定 (2)に基づき, 底角 $\alpha$ の円錐台内の各深さ位置におけるひずみ $\varepsilon(z)$ を接 合部深さ $h_{j}$ にわたって積分することでめり込み量 $\delta$; を求める（図 10d)）。なお， $\varepsilon(z)$ の算出方法については4.1.2項に示す。

\subsection{1 応力の拡がり角度 $\alpha$ の設定}

2章に示しためり込み量の推定法（式(3)）は，接合部のコンク リートが弾性範囲内にある場合の手法である。これを拡張して塑性 化後のめり込み量を推定するために，以下のような置換を行う。

図11に示すように，接触面に作用した分布荷重が接合部内に円錐 台状に拡がっていくものと仮定し, 式(3) (図2参照) と同じめり込 み量を与えるための角度 $\alpha$ を求める。

深さ $z$ では式(8)で得られる応力が円錐台の底面に均一に分布してい るものとして，ひずみを接合部の深さ区間にわたって積分してめり 込み量を求める（式(9)）。

$$
\begin{aligned}
& \sigma(z)=\frac{r^{2}}{(r+z \tan \alpha)^{2}} \sigma_{0} \\
& \delta_{j}=\int_{0}^{h_{j}} \frac{\sigma(z)}{E} d z
\end{aligned}
$$

式(3)と式(9)の右辺を等值と置くことにより， $\tan \alpha か ゙$ 定められる。接 合部内のコンクリートが塑性化しても，この角度は変化しないもの とする。

\subsection{2 強拘束領域と周辺領域の設定}

部材端部の断面曲げ解析により，コンクリートの応力ーひずみ関 係として既往のモデル（例えば，New RCプロジェクトのコンファイ ンドコンクリート18)）を用いた場合, 解析対象試験体のモーメントが 過小評価されることが明らかになった。同試験体は断面が端部で縮 小されており，支圧効果によるコンクリートの強度上昇率が大きい ためであると考え，後述する支圧効果を杭頭のコンクリートに考慮 することとした。また，基礎のコンクリートにも同様の強度上昇を 考慮する。

本論では，図 12 に示すように，支圧効果を考慮する範囲（強拘束 領域）と考慮しない範囲（周辺領域）の 2 つの領域を想定すること とした。強拘束領域の形状は，支圧面（円形）を底面とした円錐状

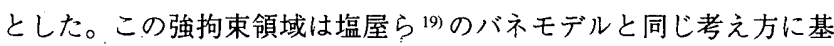

づくものであり，これを参考として底角を $\pi / 3$ とした。また，図 12 の円錐台からこの円錐部分を除いた範囲を周辺領域とした。前述の 深さ方向のひずみ分布 $\varepsilon(z)$ は, $2 \supset$ 領域のひずみが等しく一様に生 じるものとして4.1.3項に示す応力ーひずみ関媇からそれぞれの応力 を求め, それらの合力と接触面でのコンクリート負担圧縮力との釣 り合い条件から求める。

なお, 別途行った弾性 FEM 解析の結果を参考に, 杭頭の周辺領域 は杭軸とのなす角が $\pi / 6$ 以内の範囲を有効と見なし，その外側は圧縮 応力を負担しないものと仮定する。

\subsection{3 コンクリートの忘カーひずみ関係の設定}

強拘束領域と周辺領域のコンクリートの応力ーひずみ関係（以後,

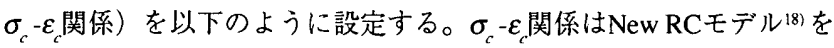
ベースにし，強拘束領域では支圧効果を考慮する（図13参照）。

\section{強拘束領域：}

文献 ${ }^{33)}$ に紹介されているNiyogi ${ }^{20)}$ の強度上昇率 $n$ を考慮する。式 (11)は無偏心の実験で得られた基本式で,これに偏心による低減率 (式(12)）を乗じて強度上昇率 $n$ を求める。 $n$ は部材溉と接合部側の それぞれについて求められる。

$$
\begin{aligned}
& n=n_{0} \cdot n_{1} \\
& n_{0}=0.42\left(\frac{a}{d}+\frac{a}{b^{\prime}}+1\right)-0.29\left[\left(\frac{a}{d}-\frac{a}{b^{\prime}}\right)^{2}+5.06\right]^{1 / 2} \\
& n_{1}=2.36\left[0.83-\left(\frac{e}{a}\right)^{2}\right]^{1 / 2}-0.94 \frac{e}{a}-1.15 \\
& \text { ここに，n：支圧効果による強度上昇率 } \\
& n_{0} \quad \text { : 强度上昇率基本式 } \\
& n_{1} \quad \text { : 偏心による低減係数 } \\
& a \text { : 支承面の幅（部材側：部材断面の短辺, 接合部 } \\
& \text { 側：接合部の材軸直交断面の短辺長さ, ) } \\
& a^{\prime}, b^{\prime} \text { : 支圧面の辺長（等面積置換した長方形の辺長） } \\
& e \quad \text { : 偏心距離 }
\end{aligned}
$$

部材・接合部ともに，プレーンコンクリートの New RC モデル 18) に支圧効果を考慮する。本論では，式(13)に示すように，ピーク時 の応力とひずみにそれぞれ強度上昇率を乗じることとした。この 方法によれば, 図14に示すように初期剛性がプレーンコンクリー トとほほ同一の $\sigma_{c}-\varepsilon_{c}$ 関係が得られる。

$$
\frac{\sigma_{c}}{n_{c} \sigma_{c B}}=\frac{A X+(D-1) X^{2}}{1+(A-2) X+D X^{2}}
$$

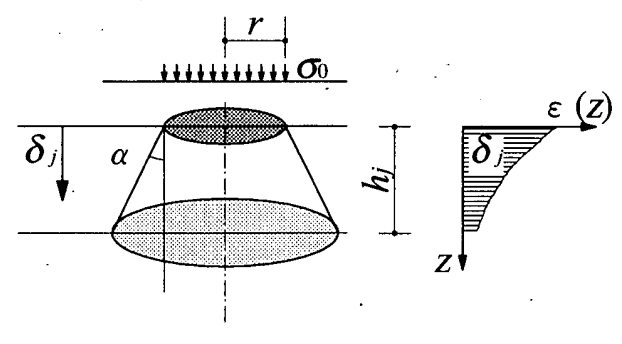

図11 応力の拡がり角度 $\alpha$

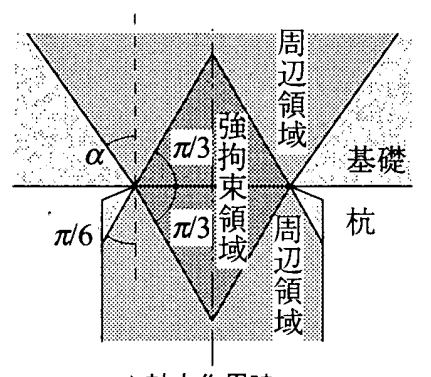

a) 軸力作用時
図12 強拘束領域と周辺領域

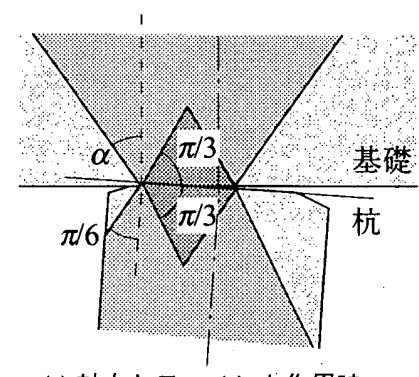

b) 軸カとモーメント作用時 


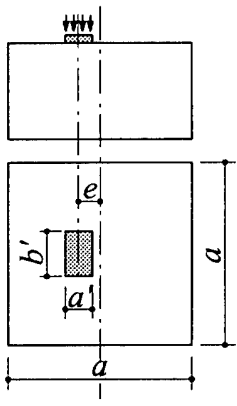

図13 コンクリートの支圧

$$
X=\frac{\varepsilon_{c}}{n \cdot \varepsilon_{c 0}}
$$

ここに, $\sigma_{c} \varepsilon_{c}:$ :コンクリートの応力とひずみ

$A, D \quad$ : New RC モデルに扔ける係数

$\sigma_{c B}, \varepsilon_{c 0}:$ New RC モデルにおけるコンクリート強度と その時のひずみ

\section{·周辺領域：}

部材の周辺領域には，フープ筋の拘束効果のみを考慮した New $\mathrm{RC}$ モデル ${ }^{18)}$ を用いる。

接合部の周辺領域にはNew RCモデル（非拘束）を用いる。た だし，周辺領域のコンクリートは接合部内の鉄筋やこの領域外の コンクリートで拘束されているため，最大強度到達後も応力は低
杭

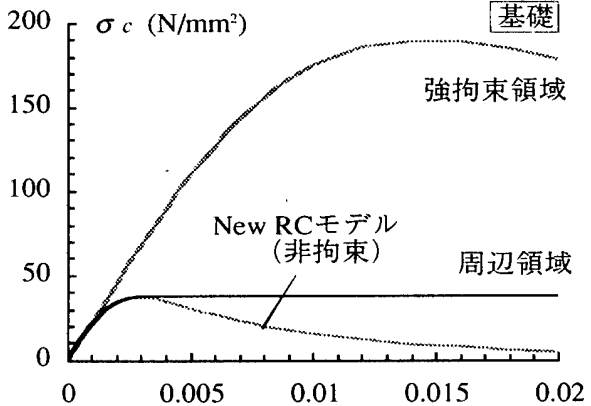

図14 コンクリートの忘カーひずみ関係

下しないものとする。

解析対象とした試験体No.1の基礎と杭頭について, 上述のモデル により求めたコンクリートの $\sigma_{-}-\varepsilon$ 関係を図 14 に示す。変形の進 行に伴い支圧面の面積が減少するとともに偏心距離も変化するので， 解析では各ステップごとに強度上昇率 $n$ を逐次求めることになる。 図 14 は, 実験での最大変形時（回転角 $0.02 \mathrm{rad}$. 時）の $\sigma_{c}-\varepsilon_{c}$ 関係 を示している。杭と基礎の応力ーひずみ関係は, 4.1節の手順 1 およ び手順 3 にそれぞれ用いられる。

\section{2 実験結果との比較}

本節では, 表1に示す 7 体の主筋非定着杭試験体を対象とした解析 の結果を実験結果と比較して示す。CFT1～-591は,コンクリート充 填鋼管杭試験体であり, 杭頭部は杭軸部より断面の小さなピースが
表1 解析対象試験体の諸元

\begin{tabular}{|c|c|c|c|c|c|c|}
\hline 試験体名 & 種別 & $\sigma_{0}$ & $\sigma_{B p}$ & $\sigma_{B b}$ & $D^{\prime} / D$ & \\
\hline No. ${ }^{5)}$ & $\mathrm{RC}$ 杭 & 10 & 51 & 37 & 0.70 & \\
\hline $\mathrm{CFT1}^{6)}$ & CFT杭 & 39 & 98 & 37 & 0.61 & 接触面の軸応力 \\
\hline CFT2 ${ }^{6}$ & CFT杭 & 26 & 98 & 35 & 0.61 & 杭頭のコン \\
\hline $\mathrm{CFT}^{6}{ }^{6}$ & CFT杭 & 13 & 98 & 37 & 0.61 & 基礎のコンクリート鸡 \\
\hline $\mathrm{CFT}^{6)}$ & CFT杭 & 51 & 98 & 35 & 0.54 & $D^{\prime} / D$ ：杭頭径と軸部径の比 \\
\hline CFT5 $^{6)}$ & CFT杭 & 34 & $203 *$ & 35 & 0.54 & * : 超高強度モルタル \\
\hline PL-5 ${ }^{7)}$ & $\mathrm{RC}$ 杭 & 5 & 28 & 35 & 1.00 & (応力の単位はいずれも $\mathrm{N} / \mathrm{mm}^{2}$ \\
\hline
\end{tabular}
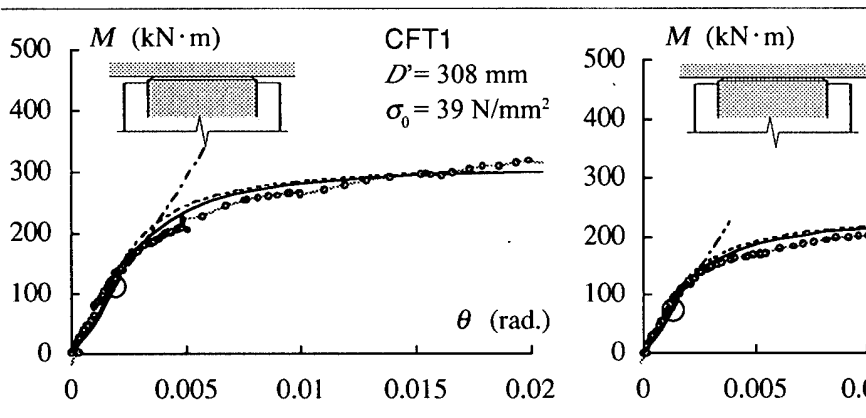

$M(\mathrm{kN} \cdot \mathrm{m})$

CFT2

$D^{\prime}=308 \mathrm{~mm}$

$\sigma_{0}=26 \mathrm{~N} / \mathrm{mm}^{2}$
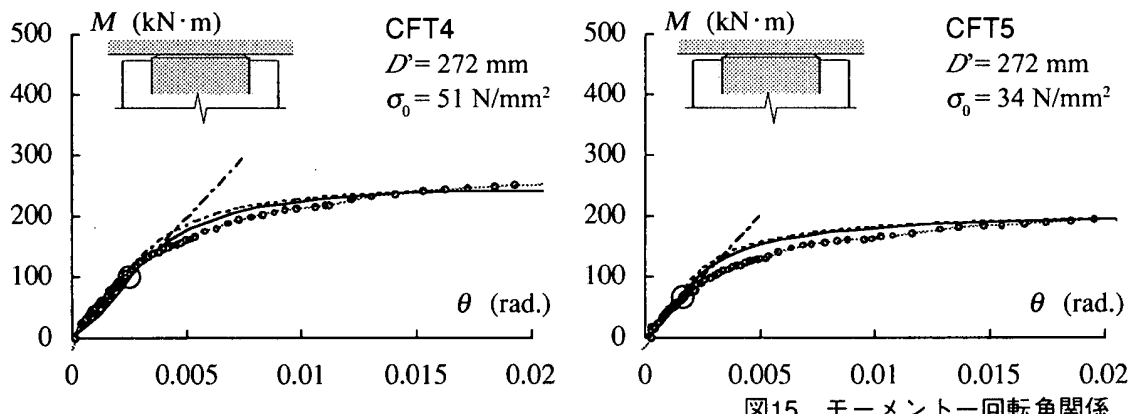
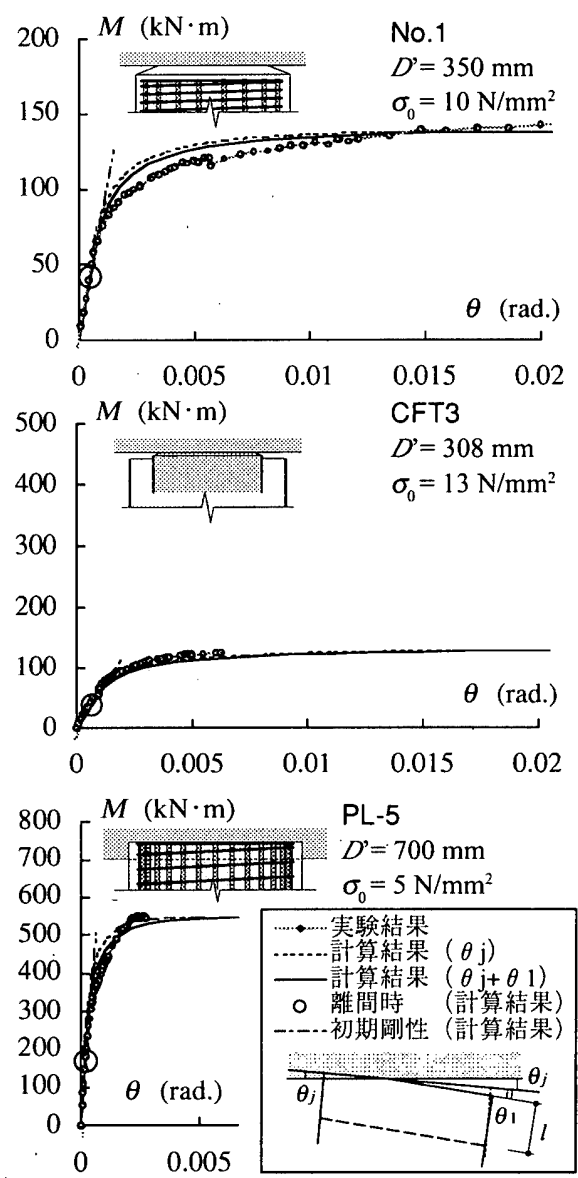
設けられている。PL-5 ${ }^{(2)}$ は主筋を非定着としたRC杭試験体で, No.1 と同じく杭主筋が基礎スタブに定着されていないが，杭頭断面は軸 部と同一寸法となっている。

\subsection{1曲げモーメント一回転角関係}

図15に杭頭の曲げモーメントと回転角の関係 (M- $\theta$ 関係)を示す。 杭頭で断面を縮小していないPL-5では, 加力により杭頭部かぶりコ ンクリートのひび割れ・圧壊が生じたため，図15では回転角計測用 の変位計が脱落するまでのデータのみを示した。他の6体では, 実験 終了後に基礎スタブに染さ $1 \sim 7 \mathrm{~mm}$ 程度（導入軸力により異なる） のくぼみが生じていたものの，杭頭および基礎スタブのコンクリー 卜の圧壊は観察されなかった。なお，CFT3では杭頭接触面ですべり が生じたため，加力が途中で終了されている。

解析において，CFT試験体では，杭頭の周辺領域にあるコンクリー トに杭頭ピースの鋼管による拘束効果を考慮した。また, PL-5では, 杭主筋は圧縮力のみを負担し，引張力は負担しないものとした。図 中の点線は解析で得られた基礎のめり込みによる変形成分 $\theta_{j}$ で, 実 線はこれに杭頭の変形成分 $\theta_{1}$ を累加した結果である。 $\theta_{1}$ は杭内部の コンクリートの応力ーひずみ関係 (4.1.2 項および4.1.3 項参照)を用 いた平面保持解析により求めた。○印は 3.1 節で述べた方法で求めた 杭頭離間時を示しており，一点鎖線はこれと原点を結んで得られる 初期剛性を示している。

試験体の変動要因が計算結果に与える影響を, ‘実験結果と比較し て以下に述べる。

·CFT杭試験体は杭頭部と基礎部のコンクリートの強度比およびヤン グ係数比がNo.1 と異なっているが, 各試験体とも良好な精度で $M$ $\theta$ 関係を予測できている。

軸応力度 $\sigma_{0}$ が異なる CFT1 C CFT3について, 実験で得られた最大 耐力の違いを適切に評価できている。なお，初期剛性は実験結果 と解析結果のいずれにおいても試験体相互の違いはない。 ・D $/ D$ が異なるCFT1 とCFT4, CFT2 とCFT5について, 初期剛性と

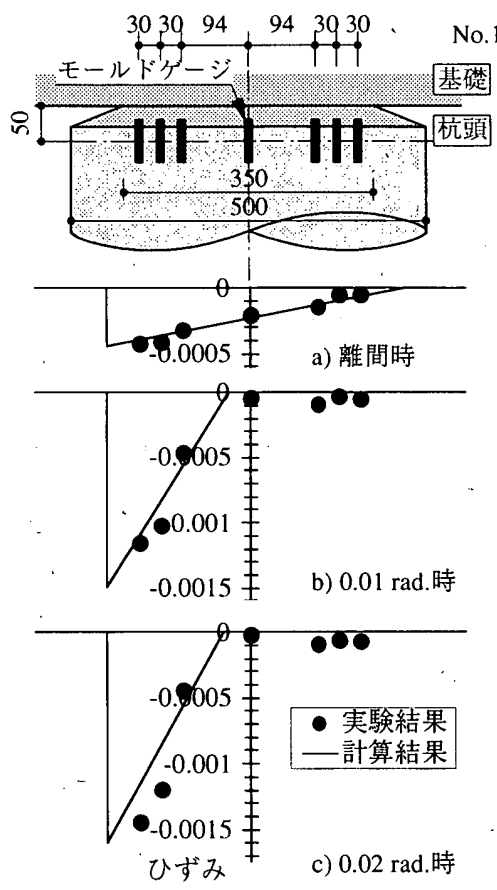

図16 コンクリートのひずみ分布
最大耐力の違いが評価できている。

・杭頭を縮小していないPL5についても，初期剛性と最大耐力は実 験結果と良好に対応している。

以上のように，本解析は種々の変動要因による影響を適切に評価 できており，初期剛性および最大酎力をいずれの試験体に対しても 精度良く推定できている。

4.2.2 杭頭のコンクリートのひずみ分布

試験体No.1 およびCFT1～CFT5では，杭頭内部のコンクリートの ひずみが計測されている。この計測断面（モールドゲージの検長区 間の中央）と同一位置におけるコンクリートのひずみ分布を解析で 求めた。試験体No.1について, 実験結果と計算結果を比較して図 16 に示す。図は，回転角が異なる 3 つのステップについて，それぞれ 示している。

ここで示していない試験体CFT1～CFT5を含む全ての試験体にお いて，各ステップのひずみ分布は実験結果と整合しており；モーメ ントと曲率の関係が精度良く推定できていると言える。

4.2.1項および4.2.2項に示した実験との比較結果から棇合的に判断 して，本解析で設定した仮定が妥当であったものと考えられる。

5. まとめ

本論文では，部材と接合部との間に生じる局部的な回転変形のう ち, 部材が接合部にめり込むことによって生じる変形に着目し，こ れを定量的に評価するための一つの手法を提案した。手法の概要と, 実験結果との比較から得られた知見は以下の通りである。

1.軸力によって部材が接合部にめり込む量は,弾性論を応用した手法 によって推定可能である。

2. 曲げモーメント一回転角関係における初期剛性は, 離間時の応力重 心位置におけるめり込み量と回転中心位置を推定することによって 適切に推定することが出来る。なおこのめり込みによって生じる 回転角は部材端部での回転角の大部分を占める場合がありこれを 適切に評価する重要性が確認された。

3.「2.」に示した回転剛性を考慮することにより，部材のせん断力ー 水平変位関係上の剛性が精度良く推定できる。これまで常用されて いる可撓長さを仮定して求める手法とは異なり,部材断面が軸方向 に一様でない場合についても容易に推定できる。

4. 部材端部でのめり込みによる回転変形が支配的となる主筋非定着杭 試験体を例に, 部材端部の曲げモーメントー回転角関倸を簡便に推 定する手法を示した。この手法によりコンクリートの断面ひずみ分 布も含めて実験結果を精度良く追跡できることを確認した。 なお，本論文で示した手法にはいくつかの仮定を採用しているがそ の適用範囲は明確でなく, 論文内で検証対象とした試験体と諸元が 大きく異なる場合, 例えば部材の断面形状が扁平である場合などに は適用に検討を要すると考えられる。また，本論文で示した手法は 回転角が単調増加する場合を主な対象としたものであり, 部材およ び接合部のコンクリート強度に対する軸応力度が大きく, 繰り返し 載荷によるひずみの蓄積が無視できない場合には推定精度が低下す ると推測される。

本論文では検討を容易にするために主筋の抜け出しを考慮しなく て良い場合 (主筋非定着杭および通常の RC部材の曲げひび割れ発生 以前）を対象とした。今後は, 主筋が接合部に定着される一般の RC 
部材にも本論文の考え方を応用して,めり込みによって断面圧縮側に 生じる回転角と主筋の抜け出しによって断面引張側に生じる回転角の 変形適合条件 (図1参照) に基づいて曲げモーメントー回転角関係を 推定する方法が構築できると考えている。

\section{参考文献}

1）村松晃次, 小室努, 川端一三, 森田寛, 原孝文, 是永健好: 鉄筋コンクリ一 ト造フレーム架構の耐震性能に関する考察 (その2:安全限界の評価)，日 本建築学会大会学術講演梗概集C-2, pp.641-642,2001 年9月

2）日本建築学会:鉄筋コンクリート造建物の勒性保証型耐震設計指針・同解 説, 1999 年 8 月

3) 寺闺勝, 狩野昘一, 佐々木聡: RC 造内柱・梁部分架構における梁部材の 降伏変形の訳価，コンクリート乙学年次論文集, Vol.16, No.2, pp.723-728, 1994 年 6 月

4）森田司郎，角徹三：鉄筋コンクリート柱・はり接合部におけるはり軸筋の 接合部からの抜け出しについて, 日本建築学会大会学術講演梗概集（構造 系），pp.1099-1100，1972年10月

5) 小林勝己, 丸隆宏, 大西靖和, 寺岡勝, 和田章: 水平力を受ける場所打方 杭一基礎梁部分架構の力学的特性に関する研究, 日本建築学会棈造系諭文 集, 第509号, pp.83-90，1998 年 7 月

6) 是永健好, 竹崎真一, 小室努, 川端一三: 超高強度材料を用いた RC 柱の 構造性能(その 2 実験結果の検討), 日本建築学会大会学術講演梗概集C2 , pp.39-40, 1997 年 9 月

7) 小室努, 渡辺英義, 是永健好, 川端一三: $150 \mathrm{~N} / \mathrm{mm}^{2}$ 級の超高強度コンク リートを用いたRC柱の構造性能 (その 1 実験計画および実験結果) (そ の 2 結果の検討), 日本建築学会大会学術講演梗概集C-2, pp.409-410, 2002 年 8 月

8) 安田聡，小室努，辰濃達，川端一三：杭主筋を基礎に定着しない杭頭接合 部の構造性能, コンクリート工学年次論文集, Vol.24, No.2, pp.1585-1590,
2002 年 6 月

9）藤山淳司, 小林祥一, 篠崎洋三, 森田仁彦, 今外和正, 山川需二郎, 井.上 哲士朗：杭頭接合法の開発に関する実験的研究 (その1 奏験概要)(その 2 実験結果と考察)，日本建築学会大会学術講演梗概集B-1, pp.459-462, 2001 年 9 月

10) 最上武雄 編著：土質力学,技報堂，1969 年 8 月

11) 日本建築学会：建築基礎構造設計指針，1988 年 1 月

12) 是永健好, 勝倉靖, 小室努, 川端一三: 異形 PC 鋼棒で横補強した場所打 $\mathrm{RC}$ 杭の大型模型実験, コンクリート工学年次論文集, Vol.21, No.3, pp.475480,1999 年 6 月

13) 日本建築学会:鉄筋コンクリート終局強度設計に関する資料, 1987华9月

14) 是永健好，小林淳，小室努，川端一三：異形 PC 鋼棒で横補強されした場 所打 RC 杭のせん断性状, コンクリート工学年次論文集, Vol.20, No.3, pp.427-432，1998 作 6 月

15) 勝倉靖, 今井和正, 竹猗真一, 是永健好, 福島順一, 小會桂治: 炭素繊維 シートで補強されたR C 柱の構造性能 (その 1 実験結果), 日本建築学会大 会学術講演梗概集C-II，pp.295-296，1996 年9月

16) 今井和正, 是永健好, 小林淳, 福島順一：炭素繊維シートで補強された $R$ $\mathrm{C}$ 柱の構造性能(その 2 丸堸柱の構造性能と高軸力下の性状), 日本建築学 会大会学術講演梗概集C-II，pp.681-682，1997年9月

17) 岡西努, 山田周平, 野村進, 谷木兼介, 今井和正, 小林淳：床仕上げ部を 巻かない炭素繊維シート補強 R C 柱の構造性能確認実験, 日本建築学会大 会学術講演梗概集C-II, pp.691-692,1997年9月

18）建設省総合技術開発プロジェクト：鉄筋コンクリート造建築物の超軽量 化·超高層化技術の開発 平成 4 年度高強度鉄筋分科会コンファインドコ ンクリートWG 報告書, 1993 年 3 月

19) 松元秀樹, 塩屋晋一, 德広育夫：コンクリート部材の中心圧縮性状と曲げ 圧篗特性の相関性に関する研究（その2 圧縮破壊領域内の応力ーひずみ関 係の検討)，日本建築学会大会学術講演梗概集C-II , pp.485-486, 1996年9月

20) Niyogi,S.K : Journal of the Structural Division, ASCE, Vol.99, No.ST7, pp.1471-1490, 1973.7 